\title{
Interpreting Proverbs 22:1 in Light of Attitude to Money in African Perspective
}

\author{
Solomon Olusola Ademiluka (UNISA)
}

\begin{abstract}
Proverbs 22:1 accords premium to "a good name" above riches. The book belongs to the OT wisdom tradition which has been adjudged as most suitable for character teaching. Hence, this study examines the text in the light of the concept of character, with specific focus on attitude to money in Africa, using the Nigerian context as an illustration. The work proposes that Prov 22:1 is relevant in contemporary Africa where the loss of regard for reputation has led to corruption and the concomitant unemployment and poverty. Recent events in Nigeria, for instance, have shown a total break-down of respect for the age-long African value system so much that exconvicts of corruption are actually celebrated on release from jail. The work therefore calls for a reawakening of the traditional African value system in which theft was more or less a taboo as people aspired for the ideals of "a good name." To achieve this there is a need for African leaders to engender policies that would enforce the traditional values to be inculcated in their subjects. More importantly, leaders at all spheres of the African community must lead by example in the aspiration for the ideals of "a good name."
\end{abstract}

\section{A INTRODUCTION}

A good name is rather to be chosen than great riches, and loving favour rather than silver and gold (Prov 22:1, KJV).

The book of Proverbs belongs to the wisdom literature of the OT. Wisdom teaching focuses on the ideals of life, providing precepts on how to live responsibly in the society. This literature is therefore most suitable for character teaching in all ages and cultures. The present work focuses on Prov 22:1 with its premium on "a good name" above riches. It examines the text in light of the concept of character, with specific focus on attitude to money in Africa. Using Nigeria as an illustration, the article assesses the relevance of Prov 22:1 for contemporary Africa where the loss of regard for reputation has led to corruption and the concomitant unemployment and poverty.

* Submitted: 25/06/2017; peer-reviewed: 10/08/2017; accepted: 21/09/2017. Solomon Olusola Ademiluka, "Interpreting Proverbs 22:1 in Light of Attitude to Money in African Perspective," OTE 31 no. 1 (2018): 164-183. DOI: https://doi.org/ $\underline{10.17159 / 2312-3621 / 2018 / \mathrm{v} 31 \mathrm{n} 1 \mathrm{a} 9 .}$. 
The work begins by examining the book of Proverbs in the context of OT wisdom tradition; it also looks at its contents and background. It identifies a correlation between character and name in African thought, and traces the high rate of corruption in the continent to the loss of regard for the ideals of "a good name." Finally, the article finds a solution for this menace in Africans imbibing the ideals of "a good name" as intended in Prov 22:1.

\section{B THE BOOK OF PROVERBS IN THE CONTEXT OF OLD TESTAMENT WISDOM TRADITION}

The books of Proverbs, Job and Ecclesiastes belong to the so-called wisdom literature of the OT. They are termed wisdom books because the words hokma and hakam are frequently found in them. According to Whybray, the root $h \mathrm{~km}$ is found in these three books 189 times out of the 346 occurrences in the OT. In books other than the wisdom books, "wisdom" refers to "skills in relation to the working of crafts, the giving of advice or shrewd counsel, the managing of people or tasks, or intellectual acumen." ${ }^{\prime 1}$ Lucas also affirms that the term is used for tailors (Exod 28:3), tabernacle and temple workers such as metalworkers, stonecutters, wood-carvers, embroiderers, weavers, and designers (35:30-36:2; 1 Kgs 7:13-14; 1 Chr 22:15; 2 Chr 2:7, 13-14), and "women who spun yarn and linen" (35:25-26); all had wisdom for their tasks ${ }^{2}$. Similarly, workmen who made idols (Isa 40:20; Jer 10:9) were also said to be wise because of their skilled craftsmanship, just as the sailors of Phoenician Ezek 27:8 are called "skilled men" (RSV, "wise men" in KJV). "Wisdom" is also used to describe the activities of women skilful (hakamot) in mourning who were hired to wail in times of desolation (Jer 9:17). ${ }^{3}$

Hokmah refers also to skill in advising and/or administering. Hence, elders of the tribes (Deut1:13,15), Joseph and Daniel in their high administrative posts (Gen 41:33-39; Dan 5:11, 29) and King Solomon (1 Kgs 3:12, 28; 5:7, 12; 10:23-24) were all men reckoned to be wise in view of their responsibility to exercise justice, make correct decisions, and provide leadership. The term sometimes suggests shrewdness or craftiness, as in the counsel given by Jonadab (2 Sam 13:3), a woman of Tekoa (14:2), and a woman of Abel Beth Maacah

1 Cited by Roy B. Zack, "A Theology of the Wisdom Books and the Song of Songs," in A Biblical Theology of the Old Testament, ed. Roy B. Zack (Chicago: Moody Press, 1991), 210.

2 Ernest C. Lucas, Proverbs (Grand Rapids: William B. Eerdmans, 2015), 1.

3 Lucas, Proverbs, 1. 
(20:14-16). ${ }^{4}$ Sometimes, hokmah may refer to occult powers as in Egypt in Joseph's day (Gen 41:8) and in Moses' time (Exod 7:11), just as Babylon had such men in Daniel's day (Dan 2:12-14, 18, 24, 48; 4:6, 18; 5:7-8, 15). These men in the king's court were possibly sorcerers and diviners, men who had learned the skills of interpreting dreams and using occult powers.

According to Zack, ${ }^{5}$ hokmah is also used of intellectual acumen as in Solomon's composing of proverbs and songs, and teaching of botanical and zoological subjects (1 Kgs 4:29-34). Intelligence in Joseph as recognized by Pharaoh was also hokmah (Gen 41:33, 39). Zack is therefore correct when he remarks that occurrences of hokmah outside the wisdom books speak of the "practical art of being skilful and successful in life," of "superior intelligence which knows how to achieve success." The scholar identifies some synonyms of hokmah, words that point to shades of thought close in meaning to hokmah. The noun binah (understanding) and the adjective nabon are used parallel to hokmah. For example, Joseph was a discerning (nabon) and wise (hakam) man (Gen $41: 33,39)$. The idea of intelligence is clearly seen in David, who was literally "intelligent (nabon) of speech" (1 Sam16:18). Another synonym is tebunah, (understanding or insight) which occurs together with hokmah in Exod 31:3; 35:31; 36:1 and $1 \mathrm{Kgs}$ 7:14. Other synonyms are used in Prov 1:2-7 such as da' at (knowledge), musar (discipline) (vv.2-3, 7), sakel (prudence) (v.3), ormah (shrewdness) (v.4), m $^{e}$ immah (discretion or wise planning) (v.4), and tahbulot (guidance). In the conclusion of Zack,

This rich vocabulary for wisdom -skill, understanding, discernment, insight, knowledge, discipline, prudence, shrewdness, planning, guidance - points to the practical nature of Old Testament wisdom ... Certainly the uses of hokmah in relation to skills would suggest that biblical wisdom includes the art of being skilful and successful in one's relationships and responsibilities in life. ${ }^{7}$

In the wisdom books, particularly, hokmah applies to "a reflection upon lived experience of quite mundane kinds." "Whereas "historical faith" tends to focus on topics like the Exodus, the entry into the land, and the exile, wisdom lays emphasis on daily human activities and behaviours bothering on matters such as speech, money, friendship, work, etc. As Birch et al. put it, wisdom literature insists that each of these mundane matters is "shot through with ethical significance and ethical outcomes, so that wise living consists in respecting the "givens" of daily life, in making responsible choices about daily existence and

\footnotetext{
4 Cf. Lucas, Proverbs, 1.

5 Zack, "Theology of the Wisdom Books," 210.

6 Zack, "Theology of the Wisdom Books," 212.

7 Zack, "Theology of the Wisdom Books," 212; cf. Lucas, Proverbs, 2.

8 Bruce C. Birch, et al., A Theological Introduction to the Old Testament, 2nd ed. (Nashville: Abingdon, 2005), 383.
} 
in anticipating the consequences of those choices." $"$ Thus, the wisdom books of the OT are not simply inventories of experience but are "reflections and interpretations of experience that are crafted in artistic speech that intends to be compelling and persuasive." 10 In the view of Birch et al., while the methods and modes of knowing of the wisdom teachers do not correspond to modern science, we may say that "the wisdom teachers approximate a scientific understanding of reality." That is, "they observe the orderly patterns of reality on the assumption of the constancy and reliability of reality." ${ }^{11}$ Having made observations for a long time, wisdom teachers are in position to predict events. The scholars are therefore right in saying,

Wisdom teaching is not simply common sense but is studied reflective judgment about reality that provides reliable lore transmitted to the next generation about how to live well, safely, responsibly, and happily. ${ }^{12}$

It is important to note that wisdom tradition is not unique to Israel. In fact, some believe that Israel borrowed its wisdom tradition from other nations. This view must have derived from the discovery of proverbs from "Sumeria and Babylon that date before 2000 BCE," many of which share similarities with "their counterparts in the Book of Proverbs."13 Attention has often been called to the discovery in 1926 of the Egyptian document called Instructions of Amenem-opet which dates to eighth-seventh centuries BCE, and has many proverbs parallel to those found in the book of Proverbs. ${ }^{14}$ Rylaarsdam ${ }^{15}$ believes this document was utilized in Prov 22:17-24:22 but Boadt ${ }^{16}$ says both the Egyptian and biblical writers probably used a common source. However, $\mathrm{Ne}^{17}$ observes that the context of Israelite wisdom is not confined only to that of the ANE but shares in the wisdom traditions of all peoples. Thus, Nel is in support of the opinion that even the proverbs of the king of Israel did not necessarily originate at the royal court but may be part of the general popular saying, as is indeed the case in Africa; the proposition which corroborates the validity of the interpretation of Proverbs in African perspective as intended in this work.

9 Birch, et al., Theological Introduction, 383.

10 Birch, et al., Theological Introduction, 383.

11 Birch, et al., Theological Introduction, 383.

12 Birch, et al., Theological Introduction, 383.

13 Coert J. Rylaarsdam, "Hebrew Wisdom," in Peake's Commentary on the Bible, ed. Harold H. Rowley and Matthew Black (Wokingham: Van Nostrand Reinhold, 1982), 386.

14 Rylaarsdam, "Hebrew Wisdom," 386.

15 Rylaarsdam, "Hebrew Wisdom," 386.

16 Lawrence Boadt, Reading the Old Testament: An Introduction (New York: Paulist, 1984), 477.

17 Philip Nel, "The Voice of Ms Wisdom: Wisdom as Intertext," OTE 9/3 (1996): 426. 


\section{THE BOOK OF PROVERBS: ITS CONTENTS, BACKGROUND AND THE GENRE mashal}

Many scholars recognize seven basic sections in the present form of the book of Proverbs. Apart from the "Prologue" in chs. 1-9, all the sections are primarily collections of individual proverbs with no absolutely clear order that governs their arrangement. ${ }^{18}$ According to Lucas, ${ }^{19}$ for much of the twentieth-century it was generally maintained that the book of Proverbs and much of its content, originated among scribal circles associated with the royal court in Jerusalem. Evidence for this view was obtained from the references to Solomon in Prov 1:1 and 10:1 and to the activity of Hezekiah's men collecting Solomonic proverbs in 25:1. The discovery of links with Amen-em-opet mentioned above gave weight to this view because of the perceived connection between Egyptian instructions and the Egyptian court. By analogy with the situation in Egypt and Mesopotamia it was assumed that there were "wisdom schools" in Israel and Judah for training scribes and maybe other courtiers, particularly in connection with the court and temple in Jerusalem. Collections of proverbs, it was agreed, would have been used for teaching in this context. Rylaarsdam ${ }^{20}$ opines that as in Egypt and elsewhere, in Israel wisdom originally flourished at the court. This is clear not only from the references in Kings but also from the contents and spirit of the wisdom literature. As the monarch who introduced the oriental court in Israel, and who had close cultural and economic relations with both Egypt and Phoenicia, Solomon may well have established a school of wisdom. The type of circle Solomon may have sponsored must have stood in close relation to the soph ${ }^{e}$ rim, the scribes (cf. Ps 45:2) who were distinguished not only by the fact that they could write but probably also knew foreign languages. In view of Prov 25:1, the writing down and copying of wisdom teaching was apparently an established practice in the time of Hezekiah, and may have begun earlier. Rylaarsdam argues that in Egypt the sayings of the wise were handed down in the form of "copy books" for pupils over many centuries, and something comparable probably took place in Israel.

However, Lucas ${ }^{21}$ reports that as early as 1913 Eissfeldt suggested that Proverbs includes some popular sayings that had originally been transmitted orally. Eissfeldt had argued that the book contains some single-line proverbs which were "folk proverbs" but were later expanded into two-line "wisdom sayings". Similarly, Westermann argued that much of the material in Prov 10:122:16 and 25-29 was orally transmitted Israelite folk wisdom from the premonarchic era, which makes it comparable to that of "other pre-literate, tribal cultures, especially African ones, whose proverbs have been collected, and so

\footnotetext{
18 Boadt, Reading, 480.

19 Lucas, Proverbs, 38.

20 Rylaarsdam, "Hebrew Wisdom," 387.

21 Lucas, Proverbs, 38.
} 
made available for study." 22 This suggestion of a pre-literate origin of the sayings in Proverbs is supported by Birch et al. when they say that it is most likely that the proverbial sayings arise in the context of a family, clan, or tribe in which "older members are constantly occupied with socializing the young into a set of assumptions, attitudes, and behaviours." ${ }^{23}$ However, they are quick to remark that what we have in the book of Proverbs in its present form is not a set of freefloating, ad hoc sayings. It is clear that these proverbs, from whatever sources, have now been collected and grouped into stable, intentional collections in order to create a durable body of interpretation and reflection. The scholars also observe that the process of collecting and editing could not have been the work of "relatively unreflective folk" but more likely the achievement of a quite intentional intellectual community. Thus, the initial utterance of proverbs and the collection of proverbs into intentional bodies of material are likely quite separate projects, undertaken by distinct groups of people in different contexts for different purposes.

This conclusion finds expression in Boadt, namely that there are two major sources suggested for Israel's wisdom. One is the family, which may correspond with the oral source, while the other is formal education in the royal administration. According to him, the first suggestion arises from the lists of proverbs which dwell on the relations of parents and children, education, and moral instruction of the young. For example, Prov 4:3 tells us, "When I was a boy in my father's house, still tender and my mother's only child, he taught me and said, 'Take my words to heart!" ${ }^{24}$ Boadt provides a probable proof for the second source in the existence of a professional class of wise men which would in turn require formal schools. He buttresses this suggestion from both Sumerian and Babylonian societies which had similar schools where young boys learned how to be scribes to prepare them for careers in the royal court or the temples. The scholar further makes reference to portions of the Bible which indicate that Israel had its professional scribes like other nations (cf. 1 Chr 27:32-33; Prov 25:1; Sir 38:24-39:11. $)^{25}$

Hence, there seems to be a need to recognize a diversity of origins for the material in Proverbs. Some of the proverbs have a "folk" origin, and there is evidence that the book as we have it is a later compilation of a number of preexisting collections. Lucas seems to support this conclusion, saying that the literary quality of many of the sentence proverbs and of the more complex instruction form found particularly in Prov 1-9, suggests the activity of professional teachers.

22 Cited by Lucas, Proverbs, 38.

23 Birch, et al., Theological Introduction, 385.

24 Boadt, Reading, 477.

25 Boadt, Reading, 477. 
It is difficult to imagine the production (and use) of such didactic collections of proverbs, and certainly an anthology of such collections (a book), in anything other than an elite intellectual environment. ${ }^{26}$

This conclusion buttresses the fact that the book is the product of a scribal elite; and in view of 25:1 the scribal elite most likely had a connection with the royal court. In the words of Birch et al.

we may propose that the collection of wisdom teaching was done by functionaries of the king whom we may describe as scribes, though other scholars sometimes use the word sage. ${ }^{27}$

Gertz et al. find the most likely application of Proverbs in "the instruction of young members of the Jerusalem upper class in the period of emergent Hellenism in the $4 \mathrm{th} / 3 \mathrm{rd}$ century BCE." 28

The book of Proverbs is dominated by the genre designated in Hebrew as mashal, "the plural form of which identifies the book". ${ }^{29}$ According to Rylaarsdam, literarily, "the mashal is the proverb, in its simplest form a couplet in which the two lines are parallel to each other, either antithetically or synthetically." ${ }^{30}$ Conversely, many believe that the exact sense of the word is unclear. As a verb it means "to rule" but as used in Proverbs it could come from a verb meaning "to be like" 31 and so means a comparison. In addition, the term mashal is applied to sayings, which have a wide variety of literary forms, such as a satirical poem (Isa 14:4), a psalm (Ps 78:2), and an allegory (Ezek 17:2). ${ }^{32}$ A mashal may further be a "taunt song" (Isa 14:4ff.; Mic 2:4f.; Hab 2:6ff.) or a "by word" (Deut 28:37; Ps 44:14; 69:11f; Ezek 14:8), both of which embody something of the force of a curse. It is also used of the ecstatic prophetic visions of Balaam (Num 24:3,15) in which the word of the seer is a "likeness" of the destiny of Israel that tends to its realization. ${ }^{33}$ The word, therefore, does not seem to refer to a specific literary form. Fox ${ }^{34}$ argues that the main characteristic of a mashal is that it "has currency among people." For example, the saying, "Is Saul too among the prophets?" (1 Sam 10:12) became a mashal by repetition so that it gained currency among people. But in the view of Crenshaw, "since Israel's

26 Lucas, Proverbs, 43.

27 Birch, et al., Theological Introduction, 394.

28 John C. Gertz, Angelika Berlejung, Konrad Schmid, and Markus Witte, $T$ \& T Clark Handbook of the Old Testament: An Introduction to the Literature, Religion and History of the Old Testament (London: T \& T Clark, 2012), 582.

29 James L. Crenshaw, Old Testament Wisdom: An Introduction (Atlanta: John Knox Press, 1981), 67.

30 Rylaarsdam, "Hebrew Wisdom," 386.

31 Lucas, Proverbs, 2; Crenshaw, Old Testament Wisdom, 67.

32 Lucas, Proverbs, 2.

33 Cf. Rylaarsdam, "Hebrew Wisdom," 386.

34 Cited by Lucas, Proverbs, 2. 
sages seem never to have adopted a single notion, we should be content with a broad definition," and for this reason, "saying" "best retains the openness of the word mashal." 35

\section{PROVERBS 22:1 AND ATTITUDE TO MONEY}

Since attitude to money subsumes under character, it is necessary to start here by examining the teachings of Proverbs in relation to character. In fact, the central subject of the book can be said to be the theme of character. Using the form of mashal, the book contains numerous teachings on character, forms of behaviour that would create a world of meaning and establish "the foundations for order and a meaningful life." ${ }^{36}$ Proverbs identifies two forms of conduct, two paths followed by all humans. Summarizing Zack, the two paths are those of righteous living and wicked living, sometimes also called wise conduct and foolish conduct respectively. "The path of righteousness or wisdom is the path of virtue, whereas the path of wickedness or folly is the path of vice." The lifestyle of the former brings blessing, and that of the latter bane. "Wickedness takes a person on a path of darkness and crookedness" (cf. $2: 13-15 ; 4: 19$ ); it is a deviant path, leading to loss of blessing, including death (cf. $2: 18 ; 8: 36 ; 11: 19 ; 14: 12$ ). ${ }^{37}$

Proverbs mentions certain virtues which indicate the path of wisdom/righteousness and vices that show the way of the wicked/foolish. Thus, Prov 22:1 teaches that it is virtuous to choose a good name above riches. The

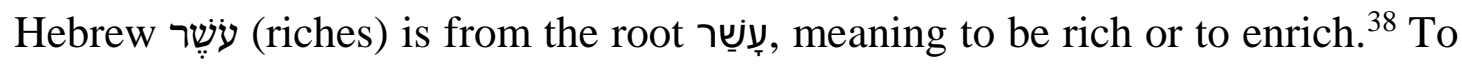
some extent Prov 22:1 reflects the OT ambivalent attitude respecting wealth and riches. According to Allen, ${ }^{39}$ while riches are sometimes seen as "the blessing of Yahweh to the righteous," "the reward of humble faith," "the gain of wisdom," "the reward of valour," "the result of diligent labour (see Ps 112:3; Prov 10:22; 1Sam 2:7; Prov 22:4; 10:4; 14:24), at other times they are portrayed as capable of leading to "self-dependence rather than dependence upon Yahweh" (Hos 12:8 [H 9]); and "may derive from deceit and treachery" (Jer 5:27). Psalm 49:1-2, 1617,20 reflects upon the futility of wealth, asserting that in the end "you can't take it with you." 40 Thus, the evil that is associated with wealth in the OT is not in the possessions themselves but in one's attitude towards them. As Allen rightly observes, this

tension between the benefits and dangers of riches is well expressed in the sage's prayer: "Give me neither poverty nor riches, feed me with the food that is my portion, lest I be full and deny thee and say

35 Crenshaw, Old Testament Wisdom, 67.

36 Nel, "Voice of Ms Wisdom," 442.

37 Zack, "Theology of the Wisdom Books," 241.

38 See Ronald B. Allen, "עשר?,'TWOT 2 vols.: 706.

39 Allen, TWOT 2 vols.: 706.

40 See Birch, et al., Theological Introduction, 418. 
172 Ademiluka, "Interpreting Proverbs 22:1," OTE 31/1 (2018): 164-183

'Who is the Lord?' or lest I be in want and steal and profane the name of my God"41 (Prov 30:8-9).

Crenshaw affirms that this prayer reveals that "Wealth is one such sign of favour that carries concealed within its train the possibility of great spiritual deprivation." 42

Proverbs 22:1 is best understood against this background of the OT ambivalent attitude to riches. A good name is rather to be chosen than great riches, and loving favour rather than silver and gold" (KJV). The King James Version is perhaps the closest to the Hebrew, many of the modern versions being attempts to interpret the KJV. In the Hebrew, we have the so-called synthetic parallelism, where the thought in the second couplet is continuous with that of the first; ${ }^{43}$ or the form which Crenshaw calls a synonymous parallelism, which "reinforces an astute observation by repetition of the essential point in different words." ${ }^{44}$ In this case, the thought of name and riches in the first couplet is continued in the second with the ideas of honour and silver/gold. The similarity between riches and silver/gold is also identified in the concepts of name and honour because a good name would usually attract honour. Hence, we concentrate on the first couplet, especially as we are concerned here with the concept of name in the context of character. As Gill rightly affirms, the word "good" is not in the Hebrew text but is rightly supplied, as it is by the Targum, Septuagint, and Vulgate Latin versions; "for it is not any name that is more eligible than riches but a good one; this is to be preferred to a multitude of riches." 45

Similarly, Tate says that "the Masoretic text has no word for good, but the idea is that of a reputation which is preferable to riches, so good" 46 is implied. The critical verb here is "chosen." In Hebrew it is the nip "al participle of the verb בהר that is used (נִבְָר), meaning a (good) name being chosen is greater than great riches; that is, it is better to have a good name than to have great riches. This interpretation is in agreement with some modern translations. For example, the NIV has "A good name is more desirable than great riches; to be esteemed is

\footnotetext{
41 Allen, TWOT 2 vols.: 706.

42 Crenshaw, Old Testament Wisdom, 85.

43 Harold H. Rowley, "The Literature of the Old Testament," in Peake's Commentary on the Bible, ed. Harold H. Rowley and Matthew Black (Wokingham: Van Nostrand Reinhold, 1982), 89.

44 Crenshaw, Old Testament Wisdom, 70.

45 John Gill, "Commentary on Proverbs 22:1," The New John Gill Exposition of the Entire Bible (1999), https://tinyurl.com/y8dqwmo6.

46 Marvin E. Tate, Jr. "Proverbs," in The Broadman Bible Commentary, 5 vols., ed. Clifton J. Allen (Nashville: Broadman Press, 1971), 5:69.
} 
better than silver or gold" while the NAB translates the verse as "A good name is more desirable than great riches, and high esteem, than gold and silver."

In his commentary on Prov 22:1 Matthew Henry interprets "a good name" to mean "to be well spoken of;" a good name is "a name for good things with God and good people." According to him, this verse implies that "we should be more careful to do that by which we may get and keep a good name than that by which we may raise and increase a great estate. ${ }^{" 47}$ Most commentators interpret "a good name" here to mean a good reputation, as seen in Gill and Tate above. In Lucas' view, the text is saying "a good reputation and public approval are a firmer basis for a good life in society than wealth" (cf. 3:4; Eccl 7:1). ${ }^{48}$ As Whedon puts it, in Hebrew thought a name includes the idea of good, honourable:

as when we say a man has made himself a name, a reputation, which, when properly viewed, is more desirable than all riches. Thus, the text is saying, the approbation and goodwill of a good man is preferable to silver and gold. To a young man settling out in life a good name, worthily obtained, is better than a fortune (cf. Eccl 7:1; 2 Saml 8:13; also Prov 23:18-22). ${ }^{49}$

In the opinion of Exell, Prov 22:1 teaches that

persons who care not what they are thought are in a very likely way not to care what they do. Contempt of reputation is contrary to our worldly interests. An eminently fair character prepossesses everybody in favour of him who bears it, engages friendly treatment, begets trust and confidence, gives credit and weight. ${ }^{50}$

Similarly, Constable explains the text as saying that in the modern world, character and reputation are no more taken seriously, but we must realize that true value is not in what one has but in what one truly is. "A good name is an asset whose currency is unaffected by the boom or bust of the material world." 51 Thus, readers of Prov 22:1 are being enjoined to be more careful "to pursue that course of life, and do those things, by which we may obtain and retain a good

47 Matthew Henry, “Complete Commentary on Proverbs 22:1," Matthew Henry Complete Commentary on the Whole Bible, https://tinyurl.com/y998sbhh.

48 Lucas, Proverbs, 149.

49 Daniel Whedon, "Commentary on Proverbs 22:1," Whedon's Commentary on the Bible, https://tinyurl.com/yccequlf.

50 Joseph S. Exell, "Commentary on Proverbs 22:1," The Biblical Illustrator, https://tinyurl.com/ya2nran4.

51 Thomas Constable, "Commentary on Proverbs 22:1," Expository Notes of Dr. Thomas Constable, https://tinyurl.com/y8g4cszd. 
name, than that way and those things by which we may raise and increase a great estate." 52

There are other portions in Proverbs which complement this verse on attitude to riches. For example, in some places it is tacitly stated that wealth is no substitute for integrity $(10: 9 ; 16: 8,19 ; 19: 1,22 ; 22: 1 ; 28: 6)$, fear of the Lord (15:16), or wisdom $(16: 16)$. Truly, using money to bribe others may be influential $(17: 8 ; 21: 14)$, but bribery is wrong $(15: 27 ; 17: 23 ; 29: 14)$. Money should be shared with the poor and needy $(11: 24-25 ; 14: 31 ; 19: 17 ; 21: 13 ; 22: 9$, $22 ; 28: 27)$. Bribery $(6: 35 ; 15: 27 ; 17: 8,23 ; 21: 14 ; 29: 4)$, and acquiring money by dishonesty $(10: 2 ; 13: 11 ; 28: 20,22)$ are all condemned. These are forms of human behaviour that are harmful to the community. ${ }^{53}$

\section{F PROVERBS 22:1 AND ATTITUDE TO MONEY IN AFRICA \\ $1 \quad$ African traditions on character}

Similar to the sayings in Proverbs, African traditions emphasise the significance of character in the life of every individual. Hence, in the traditional setting, good character is taught to every individual right from childhood "through a combination of precepts and oral literature such as proverbs, poems, songs, folktales, myths, etc." 54 According to Adonai, the principles of traditional education are based on the Yoruba concept of omoluabi (i.e., a person of good character). To be an omoluabi in Yoruba traditional thought is to be of good character in all aspects of life. The concept encompasses "virtues such as respect for old age, loyalty to one's parents and local traditions, honesty in all public and private dealings, devotion to duty, sociability," etc. ${ }^{55}$ Akanbi and Jekayinfa summarise the concept of omoluabi as "the standard which determines the morality and the immorality of an act in Yoruba society." ${ }^{\text {"Similarly, Abimbola }}$ considers character in Yoruba traditional culture from the perspective of the concept of iwa (character). ${ }^{57}$ According to Abimbola, one verse in ifa (oracle)

52 Joseph Benson, “Commentary on Proverbs 22:1," Joseph Benson's Commentary, https://tinyurl.com/y8ma2pwx.

53 See Nel, "Voice of Ms Wisdom," 443; Zack, "Theology of the Wisdom Books," 241-242.

54 T. Adedeji Awoniyi, "Omoluabi: The Fundamental Basis of Yoruba Traditional Education," in Yoruba Oral Tradition: Selections from Papers Presented at the Seminar on Yoruba Tradition: Poetry in Music, Dance and Drama, ed. Wande Abimbola (Ibadan: The University Press, 1975), 364.

55 Awoniyi, "Omoluabi," 364.

56 Grace O. Akanbi and Alice A. Jekayinfa, "Reviving the African Culture of 'Omoluabi' in the Yoruba Race as a Means of Adding Value to Education in Nigeria," IJMER3/3 (2016): 13-19, online: https://tinyurl.com/ya6mjyho.

57 Wande Abimbola, "The Concept of Good Character in Ifa Literary Corpus," in Yoruba Oral Tradition: Selections from Papers Presented at the Seminar on Yoruba 
teaches that patience is the most important aspect of $i w a$, hence the saying, "suuru ni baba iwa" (patience is the acme of good character). "Of all the attributes of man patience is the most important because the person who is patient takes time to consider things properly before embarking on action." ${ }^{\text {"58 }}$ In the same vein, Gbadegesin attests that iwa is, for the Yoruba, "perhaps the most important moral concept. A person is morally evaluated according to his/her $i w a-$ whether good or bad." ${ }^{59}$ Thus, the Yoruba concept of character in terms of patience is most relevant for the present study in that it is impatience that makes people to want to get rich quick, thereby diverting public money into their private accounts. As we shall see presently, the Yoruba regard such money launderers as people who do not care for the ideals of "a good name" (i.e., their reputation).

According to Gyekye, the concept of good and bad character is also expressed in the traditions of the Akan of Ghana. Among them,

pa or papa means good and bone means bad or evil. Thus, the expression onipa bone means a bad person. A bad person is said to be a person with a bad character, suban bone. When a person is known to be honest or generous or compassionate, he would be judged by the Akan as a good person, by which they mean that he has good character (suban). A person would be judged as having bad character if he is considered dishonest, wicked, or cruel. In most moral evaluations reference is made to the character of a person; thus, character is basic - the crucial element-in Akan, as it is in African, ethics generally. ${ }^{60}$

The significance of character in African thought can be summarized in the words of Gyekye thus:

African ethics is, thus, a character-based ethics that maintains that the quality of the individual's character is most fundamental in our moral life.... It is from a person's character that all his or her actions - good or bad - radiate: the performance of good or bad acts depends on the state of one's character. Wrong-doing is put down to a person's bad

Tradition: Poetry in Music, Dance and Drama, ed. Wande Abimbola (Ibadan: The University Press, 1975), 394.

58 Abimbola, "Concept of Good," 391-402, cited by S. Olusola Ademiluka, "The Deuteronomists' Accounts of the Delinquencies of David's Children: Relevance for Contemporary Africa," in The Bible and Children in Africa, BiAS 17, ed. Joachim Kügler, Lovemore Togarasei, and Eric Souga Onomo (Bamberg: University Press, 2014), 21.

59 Gbadegesin, cited by Kwame Gyekye, "African Ethics," in The Stanford Encyclopedia of Philosophy (Fall 2011 Edition), n.p. [cited 17 June 2017], (ed. Edward N. Zalta). Online: https://tinyurl.com/y9smefrg.

60 Gyekye, "African Ethics," https://tinyurl.com/y9smefrg. 
176 Ademiluka, "Interpreting Proverbs 22:1," OTE 31/1 (2018): 164-183

character. Thus, the Yoruba maxim (proverb): "Good character is a person's guard." 61

As in Proverbs, in the traditional African setting the significance of character is taught particularly in proverbs; and this is popularly attested. Owan affirms that

African wisdom finds particular expression through the instrumentality of the proverb as the traditional society of the African sees proverbs as indispensable in the formation of the cultural, ethical, and social bedrock of the society. ${ }^{62}$

The African proverb is utilized in the main areas of education, information, social control, entertainment and relaxation. Similarly, Adamo attests that the function of proverbs in Africa, as in the OT, is "to advise, encourage, reproach, and elucidate important facts," 63 so as to make life understandable and easy for living. In the same vein, Van Heerden explores the possibility and importance of dialogue between African proverbs and biblical texts, emphasizing that sometimes they share identical wordings, ideas and motifs, and literary features. ${ }^{64}$ The African proverb is most significant in the preservation of the people's tradition. A resort to proverbs on any occasion is in effect an appeal to the community to follow "the way things are, and the way things have been long before now ..." ${ }^{65}$ In expressing the importance of proverbs in African culture the Igbo of south-eastern Nigeria put it figuratively that "proverbs are the palm-oil with which words are eaten" 66 by which they mean proverbs are the lubricant of articulate and effective communication. By this fact they encourage the value and authority of proverbs in the community with regard to the society's tradition. Like the Igbo, the Yoruba believe so much in the importance and power of proverbs in communication, hence they say,

Owe l'esin oro; bi oro ba sonu, owe ni a nfi wa a (A proverb is the horse which carries a subject under discussion along; if a subject under discussion goes astray, we use a proverb to track it). ${ }^{67}$

61 Gyekye, "African Ethics,” https://tinyurl.com/y9smefrg.

62 Kris J. N. Owan, "African Proverbial Wisdom and Biblical Proverbial Wisdom: Wholesome Bedfellows and More," in BiBh 23/3 (1997): 160.

63 David T. Adamo, "Ancient Israelite and African Proverbs as Advice, Reproach, Warning, Encouragement and Explanation," HTS Teologiese Studies / Theological Studies 71/3 (2015), Art. \#2972, 11 pages, doi: 10.4102/hts.v73i3.3495.

64 Willie Van Heerden. " It's on the Old Mat that One Weaves the New One': The Dialogue between African Proverbs and Biblical Texts," OTE 19/2 (2006): 429-440.

65 Owan, "African Proverbial," 164.

66 Owan, "African Proverbial," 164.

67 Isaac O. Delano, Owe L'esin Oro: Yoruba Proverbs - Their Meaning and Usage (Ibadan: the University Press, 1983), 25, 109. 
Many African proverbs dwell on the significance of character in the life of the individual. For instance, one Yoruba proverb says, "Iwa ni orisa; bi a ba ti hu u si ni ifi gbe " $n i$ (character is god; according to the way you behave it supports you)." This implies that if you have good character you will benefit by it. This is similar to the popular saying, "As you sow, so will you reap." 68 The Yoruba have many proverbs intended to teach good character. They would say, "Iwa rere ni eso eniyan, ehin funfun ni eso oge (Good character is the adornment of man, white teeth are the adornment of a fine lady)." 69

Similar to Prov 22:1, in African thought there is a correlation between a person's character and his/her name. For example, literally, the Yoruba word for name is oruko. However, metaphorically a person may be said to have a good or bad name, depending on his/her character. If you constantly behave in a bad way, you will end up attracting a bad name to yourself. In this case the Yoruba would say, o gba oruko buruku (lit., he/she has made a bad name). This implies that the person's reputation is damaged due to his/her constant misbehaviour. In the same vein, if someone wrongly accuses you of a bad behaviour, you might tell him/her, ma so mi l'oruko (lit., "don't give me a bad named," i.e., "don't spoil my reputation"). ${ }^{70}$ Thus, in the traditional African setting, people believe that a person's character and his/her name are inseparable; that is, your character goes along with your name, whether good or bad. Due to this awareness people are expected to mind their behaviour so as not to attract bad names. And it is commonly said that in the days of yore, most people avoided bad behaviours, not only because they feared the severe punishments that went along with them but also because people cared to have good names; they did not want to get bad names. Perhaps, that is why in those days in Yorubaland, for example, cases of fighting in the public, murder, adultery and, particularly theft were very rare. ${ }^{71}$

\section{Corruption in Africa as illustration of loss of regard for the ideals of "a Good Name"}

Today in Africa there is a clear loss of regard for the traditions described above, and in the view of the present writer, this is a major cause of the current rate of corruption in the continent. In contemporary Africa, damage to name (i.e., reputation) no longer means anything to many people. That is why people are sentenced to jail for stealing, and when they come out, they show not the slightest remorse; instead some of them even go to the church to be accorded the warmest celebration by their kith and kin. Here, we shall briefly illustrate with the Nigerian context how this loss of the sense shame has driven the economy to

68 Delano, Owe L'esin Oro,82.

69 Delano, Owe L'esin Oro, 82.

70 Roy C. Abraham, Dictionary of Modern Yoruba (London: University Press, 1958), 86.

71 Ademiluka, "Deuteronomists' Accounts," 21. 
ruins. As the present writer has reiterated severally, ${ }^{72}$ conventionally, in Nigeria the political class use their privileged positions to corner a disproportionate portion of the resources, displaying ostentatious lifestyles, while the citizenry live in the midst of grinding poverty. ${ }^{73}$ Politicians and government functionaries literally engage in looting the resources of the country. In recent times, so many dignitaries of these categories have been indicted for corruption. The billions of Naira stolen by late Abacha, former military Head of State, are still being recovered by successive governments after him. Former Governor of Delta State, James Ibori was convicted in April 2012 by the Southwark Crown Court in London for money laundering valued at about 77 million dollars (about $\$ 12.17 \mathrm{bn}$ ). Hon. Farouk Lawan has been in court since 2013 for alleged graft of $\$ 620,000$. Lawan was the Chairman of the House of Representatives Subsidy Probe Panel. ${ }^{74}$ Also in 2013, two committees of the Senate alleged that Abdulrasheed Maina, Chairman, Pension Reform Task Team (PRTT) mismanaged $\$ 469$ billion pension fund. The immediate past government of Goodluck Jonathan is being probed, and revelations are being made of corruption involving billions of dollars. Former Minister of Petroleum under Jonathan, Diezani Alison-Madueke, is currently facing trial for alleged money laundering. The National Security Adviser to Jonathan, Sambo Dasuki, along with many others, is under investigation for alleged corruption involving some $\$ 2.1 \mathrm{bn} .{ }^{75}$

In Nigeria it is not only the leaders who are corrupt. The menace has become so endemic that many hardly see anything wrong with stealing public money. In fact, some refer to it as official stealing. Government money is the national cake from which everybody wants to have his/her own slice; not taking one's share when one has the "opportunity" is considered as not being smart. The cankerworm has eaten so deep into the fabric of the nation that it was recently alleged that the country has lost not less than $\$ 8$ trillion to corruption since independence. ${ }^{76}$

The nonchalant attitudes of many Nigerians towards their own reputation have led not only to corruption but also to the concomitant results of corruption, particularly unemployment and poverty. The resources that are supposed to be expended on roads, education, power and steel, agriculture, health, security, etc.

72 S. Olusola Ademiluka, "Prophetic Intervention in Eighth-Century Israel: A Recipe for Socio-Economic Recovery in Africa," Uma 2/2 (2007): 24-37; S. Olusola Ademiluka, "Interpreting the Eighth-Century Prophets in Israel in the Context of Unrest in the Niger Delta Region of Nigeria," in From Text to Practice: The Role of the Bible in Daily Living of African People Today, ed. Joachim Kügler and Masiiwa Ragies Gunda, BiAS 4 (Bamberg: University Press, 2011), 45-62.

73 See also Biodun Ogunyemi, "Beyond the Security Threats," NSch 9/1(2012): 36.

74 See S. Olusola Ademiluka, "A Narrative Reading of Exodus 1-12 as a Challenge to the Church in Nigeria," Uma 10 (2015): 27.

75 Ademiluka, "Narrative Reading," 27.

76 Enakeno Oju, "Nigerians have Stolen $\$$ 7.9 trillion," Daily Times, 14 March 2013. 
are diverted into private accounts, hence the unprecedented unemployment. As the present writer puts it in another place,

It is as if there has been a permanent embargo on employment. The number of graduates roaming the streets desperately in search of job increases yearly by the thousands. Groups of retirees and retrenched workers have joined the number of beggars on the streets. ${ }^{77}$

According to the National Bureau of Statistics (NBS), the rate of unemployment rose from $11.9 \%$ in 2005 to $23.9 \%$ in $2011 .{ }^{78}$ Unemployment fluctuated between $8 \%$ and $14 \%$ from 2014 to 2016 , rising to $14 \%$ in the last quarter of 2016. ${ }^{79}$ Unemployment is the major cause of the current unprecedented poverty in Nigeria. Even as one of the richest petroleum exporting countries of the world, Nigeria was rated recently by the UN Development Programmes as one of the 25 poorest countries of the world. ${ }^{80}$ By 2012 the percentage of Nigerians living in abject poverty increased to $69 \% .{ }^{81}$ In 2016 a UN report indicated that Nigeria is one of the poorest countries in the world with over 80 million (or $64 \%$ ) of the population living below the poverty line. ${ }^{82}$

\section{$3 \quad$ Finding a solution in Proverbs 22:1}

The illustration above traces the current poor state of Nigerian economy to corruption, which in turn derived from the loss of regard for the ideals of "a good name" as contained in African traditions and Prov 22:1. In other words, in Africa the traditional regard for the right values is lost, and this accounts for the rampant anti-social behaviour, particularly corruption. One way of curbing corruption in Africa, therefore is to reawaken the respect for African values. According to Idang,

values occupy a central place in a people's culture. It forms the major bulwark that sustains a people's culture, making it more down-toearth and real. The values of a culture find expression in the fact that

77 Ademiluka, "Prophetic Intervention," 37.

78 NBS, cited by Nwachukwu Orji and Nkiru Uzodi, Post-Election Violence in Nigeria: Experiences with the 2011 Elections (Nigeria: Policy and Legal Advocacy Centre [PLAC], 2012), online: https://tinyurl.com/y7vozf4w.

79 National Bureau of Statistics, n.p. [cited 13 September, 2017]. Online: https://tinyurl.com/ycmn3bdf.

80 Ayodeji A. Olaniyi, "The dal in Exodus 30:15 and Poverty Alleviation in Nigeria," ASUU 2/1(2012): 130.

81 Abdulwaheeb I. Omar, "The 2012 May Day Speech Presented by Comrade Abdulwaheeb Ibrahim Omar, President of the Nigeria Labour Congress (NLC) at the Eagle Square, Abuja on $1^{\text {st }}$ May, 2012," 10.

82 Seun Opejobi, "Nigeria one of the poorest countries in the World, over 80m living below Poverty Line - UN Report," DailyPost 5 Sept. 2016, online: https://tinyurl.com/ycwqufks. 
some forms of behaviour, actions and conduct are approved while others are widely disapproved of. In the traditional African culture, to show the extent of disapproval of violation of values that should otherwise be held sacred, particularly theft, the penalty was sometimes utterly shameful. ${ }^{83}$

Idang cites an example among the Ibibio of south-south Nigeria where a thief would be stripped naked and made to carry the object he/she had stolen round the village in broad daylight. The shame and the disgrace thus suffered not only by the thief but also his/her relations and friends would be enough to deter even the most daring thief. ${ }^{84}$ In fact, in some places in Yorubaland theft carried the death penalty, especially if a person became notorious for it. ${ }^{85}$ However, recent events have shown a total neglect of these age-long African values. This is demonstrated in the way ex-convicts of corruption are celebrated, particularly in Nigeria. For example, very recently, James Ibori, mentioned above, arrived home from UK and pulled a mammoth crowd of people jubilating with him. The point then is that Africans celebrate the rich even when they know that their wealth is ill-gotten. Hence, ex-convicts never show any remorse that used to be associated with theft in the traditional African community.

There is therefore the need for a reawakening of the traditional African value perception; and in this parents have the greatest role to play. In Africa parents have the responsibility to inculcate good character in their children. African folklore does in fact, have a way of taunting parents who fail in the proper upbringing of their children. The Yoruba, for example, would call "a child of notorious ant-social behaviour an abiiko (a child not properly brought up by his/her parents)." ${ }^{96}$ As Awoniyi ${ }^{87}$ rightly observes, it is most disgraceful to a Yoruba parent for his/her child to be called an abiiko. A child is better called an akoogba (a child who refuses discipline), where the failure is that of the child, and not of the parents. There is the need for a revival of these traditional precepts by means of which traditional values and virtues used to be taught to children. As suggested by Ademiluka in another work, ${ }^{88}$ one way of achieving this is for parents to maintain a mutual link with their traditional roots where some of these values are still being preserved. In contemporary Africa, many parents have lost contact with their traditional roots so much so that their children do not even have an idea of their nativity. As such children know nothing about African value perception the concept of "a good name" means nothing to them. For such children, diverting public money into private accounts, going to jail and coming

83 Gabriel E. Idang, “African Culture and Values,” Phronimon 16/2 (2015): 97-111, online: https://tinyurl.com/y74qq5xv.

84 Idang, "African Culture," https://tinyurl.com/y74qq5xv.

85 Ademiluka, "Deuteronomists' Accounts," 21.

86 Ademiluka, "Deuteronomists' Accounts," 21.

87 Awoniyi, “Omoluabi” 375.

88 Ademiluka, "Deuteronomists' Accounts," 22. 
back to be celebrated, as they watch on television, are normal life routines. To change this perception there is need for African governments to put in place policies that would enforce the traditional values to be taught at home, in the schools and on the media.

Also, religious organizations have a role to place in making their members aspire for the ideals of "a good name." Apart from Proverbs there are numerous references in the Bible that teach character in respect to attitude to riches. The church and the mosque should use relevant portions of their holy books to teach their congregations to return to the old days when people cared to have good names. However, both political and religious leaders must lead by example in their attitude to money. This call becomes necessary in view of the involvement of leaders in corruption as shown above in the case of Nigeria.

\section{G CONCLUSION}

Proverbs 22:1 puts a premium on "a good name" above riches. The whole book belongs to the OT wisdom tradition which creates awareness of the social significance of mundane day-to-day behaviour. Wisdom literature is thus most suitable for character teaching at all ages and in all cultures. Hence, this study examines Prov 22:1 in light of the concept of character with specific focus on attitude to money in Africa. The work finds relevance in contemporary Africa, accounting for the current high rate of corruption, unemployment and poverty in the continent in the nonchalant attitude of Africans to the concept of "a good name." It suggests that Prov 22:1 can be applied as a solution to this loss of regard for reputation. Recent events in respect to corruption have shown a total break-down of respect for the age-long African value system, a break-down which is shown in the way ex-convicts of corruption are celebrated, for example in Nigeria. There is therefore a need for a reawakening of the traditional African value system in which stealing was a taboo. To achieve this there is a need for African governments to put in place policies that would enforce the traditional values to be taught at home and at school. More importantly, both political and religious leaders must lead by example to inculcate the right attitude to money in their followers.

\section{BIBLIOGRAPHY}

Abimbola, Wande. "Iwapele: The Concept of Good Character in Ifa Literary Corpus." Pages391-402 in Yoruba Oral Tradition: Selections from Papers Presented at the Seminar on Yoruba Tradition: Poetry in Music, Dance and Drama. Edited by Wande Abimbola. Ibadan: University Press, 1975.

Abraham, Roy C. Dictionary of Modern Yoruba. London: University Press, 1958.

Adamo, David T. "Ancient Israelite and African Proverbs as Advice, Reproach, Warning, Encouragement and Explanation." HTS Teologiese Studies / Theological Studies 71/3 (2015). Art. \#2972. 11 pages. DOI: https://doi.org /10.4102/hts.v71i3.2972 
182 Ademiluka, "Interpreting Proverbs 22:1," OTE 31/1 (2018): 164-183

Ademiluka, S. Olusola. "Prophetic Intervention in Eighth-Century Israel: A Recipe for Socio-Economic Recovery in Africa." Uma 2/2(2007): 24-37.

. "Interpreting the Eighth-Century Prophets in Israel in the Context of Unrest in the Niger Delta Region of Nigeria." Pages 45-62 in From Text to Practice: The Role of the Bible in Daily Living of African People Today. Edited by Joachim Kügler and Masiiwa Ragies Gunda. BiAS 4. Bamberg: University Press, 2011. . "The Deuteronomists' Accounts of the Delinquencies of David's Children: Relevance for Contemporary Africa." Pages 13-26 in The Bible and Children in Africa. BiAS 17. Edited by Joachim Kügler, Lovemore Togarasei, and Eric Souga Onomo. Bamberg: University Press, 2014.

"A Narrative Reading of Exodus 1-12 as a Challenge to the Church in Nigeria." Uma 10 (2015): 13-33.

Akanbi, Grace O. and Jekayinfa, Alice A. "Reviving the African Culture of 'Omoluabi' in the Yoruba Race as a Means of Adding Value to Education in Nigeria." IJMER3/3 (2016): 13-19.Online: https://tinyurl.com/ya6mjyho.

Awoniyi, T. Adedeji. "Omoluabi: The Fundamental Basis of Yoruba Traditional Education." Pages 361-372 in Yoruba Oral Tradition: Selections from Papers Presented at the Seminar on Yoruba Tradition: Poetry in Music, Dance and Drama. Edited by Wande Abimbola. Ibadan: University Press, 1975.

Benson, Joseph. "Commentary on Proverbs 22:1." Joseph Benson's Commentary. https://tinyurl.com/y8ma2pwx.

Birch, Bruce C., Walter Brueggemann, Terence E. Fretheim, and David L. Petersen. A Theological Introduction to the Old Testament. 2nd ed. Nashville: Abingdon, 2005.

Boadt, Lawrence. Reading the Old Testament: An Introduction. New York: Paulist, 1984.

Constable, Thomas. "Commentary on Proverbs 22:1." Expository Notes of Dr Thomas Constable. https://tinyurl.com/y8g4cszd.

Crenshaw, James L. Old Testament Wisdom: An Introduction. Atlanta: John Knox Press, 1981.

Delano, Isaac O. Owe L'esin Oro: Yoruba Proverbs - Their Meaning and Usage. Ibadan: University Press, 1983.

Exell, Joseph S. "Commentary on Proverbs 22:1." The Biblical Illustrator. https://tinyurl.com/ya2nran4.

Gbadegesin, Segun. African Philosophy: Traditional Yoruba Philosophy and Contemporary African Realities. New York: Peter Lang, 1991.

Gertz, John C., Angelika Berlejung, Konrad Schmid, and Markus Witte. $T$ \& T Clark Handbook of the Old Testament: An Introduction to the Literature, Religion and History of the Old Testament. London: T \& T Clark, 2012.

Gill, John. "Commentary on Proverbs 22:1." The New John Gill Exposition of the Entire Bible (1999). https://tinyurl.com/y8dqwmo6.

Gyekye, Kwame. "African Ethics." No Pages in The Stanford Encyclopedia of Philosophy. Fall 2011 Edition. Cited 17 June 2017. Edited by Edward N. Zalta. Online: https://tinyurl.com/y9smefrg.

Harris, R. Laird, Gleason L. Archer Jr., and Bruce K. Waltke, eds. Theological Wordbook of the Old Testament. 2 vols. Chicago: Moody Publisher, 1980. 
Henry, Matthew. "Complete Commentary on Proverbs 22:1." Matthew Henry Complete Commentary on the Whole Bible. https://tinyurl.com/y998sbhh.

Idang, Gabriel E. "African Culture and Values." Phronimon 16/2 (2015): 97-111. Online: https://tinyurl.com/y74qq5xv.

Lucas, Ernest C. Proverbs. Grand Rapids: William B. Eerdmans, 2015.

Nel, Philip. "The Voice of Ms Wisdom: Wisdom as Intertext." OTE 9/3(1996): 423450.

National Bureau of Statistics. No pages. Cited 12 September, 2017. Online: https://tinyurl.com/ycmn3bdf.

Ogunyemi, Biodun. "Beyond the Security Threats." NSch 9/1(2012): 36-37.

Oju, Enakeno. "Nigerians have Stolen N7.9 trillion." Daily Times 14 March 2013.

Olaniyi, Ayodeji A. "The dal in Exodus 30:15 and Poverty Alleviation in Nigeria." ASUU 2/1 (2012): 129-140.

Omar, Abdulwaheeb I. "The 2012 May Day Speech presented by Comrade Abdulwaheeb Ibrahim Omar, President of the Nigeria Labour Congress (NLC) at the Eagle Square, Abuja on $1^{\text {st }}$ May, 2012."

Opejobi, Seun. "Nigeria one of the poorest countries in the World, over 80m Living below Poverty Line - UN Report." Daily Post 5 Sept. 2016. Online: https://tinyurl.com/ycwqufks.

Orji, Nwachukwu and Uzodi Nkiru. Post-Election Violence in Nigeria: Experiences with the 2011 Elections. Nigeria: Policy and Legal Advocacy Centre (PLAC), 2012. Online: https://tinyurl.com/y7vozf4w.

Owan, Kris J. N. "African Proverbial Wisdom and Biblical Proverbial Wisdom: Wholesome Bedfellows and More." BiBh23/3 (1997):151-173.

Rowley, Harold H. "The Literature of the Old Testament." Pages 86-90 in Peake's Commentary on the Bible. Edited by Matthew Black and Harold H. Rowley. Wokingham: Van Nostrand Reinhold, 1982.

Rylaarsdam, J. Coert. "Hebrew Wisdom." Pages 386-390 in Peake's Commentary on the Bible. Edited by Matthew Black and Harold H. Rowley. Wokingham: Van Nostrand Reinhold, 1982.

Tate, Marvin E., Jr. "Proverbs." Pages 1-99 in The Broadman Bible Commentary. 5 vols. Edited by Clifton J. Allen. Nashville: Broadman Press, 1971.

Van Heerden, Willie. "IIt's on the Old Mat that One Weaves the New One': The Dialogue between African Proverbs and Biblical Texts." OTE 19/2 (2006): 429440.

Whedon, Daniel. "Commentary on Proverbs 22:1." Whedon's Commentary on the Bible. https://tinyurl.com/yccequlf.

Zack, Roy B. "A Theology of the Wisdom Books and the Song of Songs.” Pages 207255 in A Biblical Theology of the Old Testament. Edited by Roy B. Zack. Chicago: Moody Press, 1991.

Solomon Olusola Ademiluka (Unisa), Department of Biblical and Ancient Studies, University of South Africa; Department of Religious Studies, Kogi State University, Anyigba, Nigeria; solademiluka@gmail.com; +2347036127452; All private correspondence to P. O. Box, 379, Anyigba, Kogi State, Nigeria. ORCID ID: https://orcid.org/0000-0001-9390-2510 